\title{
THE EFFECT OF LEADERSHIP AND ORGANIZATIONAL COMMITMENT TO ORGANIZATIONAL CITIZENSHIP BEHAVIOR AND WORK ACHIEVEMENT
}

\author{
(Studies on the Sports Coach Formation Civil Servants in the Bali Provincial \\ Government)
}

\author{
I Gusti Agung Ayu Diah Pramesty \\ Post Graduate Management student at the University Mahasaraswati Denpasar, Bali, Indonesia \\ Nengah Sudja \\ Associate Professor in Management Postgraduate Mahasaraswati University Denpasar Bali, Indonesia
}

Anik Yuesti

Associate Professor in Management Postgraduate Mahasaraswati University Denpasar Bali, Indonesia

DOI: $10.31364 / \mathrm{SCIRJ} / \mathrm{v} 8 . \mathrm{i} 8.2020 . \mathrm{P} 0820800$

http://dx.doi.org/10.31364/SCIRJ/v8.i8.2020.P0820800

\begin{abstract}
This study aims to examine the effect of leadership and organizational commitment on organizational citizenship behavior (OCB) and work performance in civil servants of sports coach formations in the Bali Provincial Government. The population in this study were all civil servants who were appointed to the sports coach formation in the Bali Provincial Government, totaling 32 people. Data relating to research variables were collected using a questionnaire that was distributed to all respondents and filled in by the respondents themselves based on the respondents' perceptions. Based on the instrument test performed, it was proven that all statement items in the questionnaire proved valid and reliable. This study uses Structural Equation Modeling (SEM) analysis. The results of this study indicate that: 1) leadership has a positive and significant effect on OCB, 2) organizational commitment has a negative and insignificant effect on OCB, 3) leadership has a positive and significant effect on work performance, 4) Organizational commitment has a positive and insignificant effect on achievement. work, 5) OCB has a positive and significant effect on work performance.
\end{abstract}

Keywords: Leadership, Organizational Commitment, OCB and Job Performance

\section{PRELIMINARY}

Civil Servants (PNS) are state servants who have the main task of being public servants who are required to always perform and excel in increasing knowledge, attitudes and skills in providing services to the community, especially in carrying out government tasks. Job performance isactivities and work results achieved or demonstrated by someone in carrying out work tasks. It can also be said that work performance is a manifestation or appearance in carrying out work (Supardi, 1989). Good work performance requires employees not only to do the main job (in-role) of the employee but also work that is outside the employee's main job (extra-role) (Titisari, 2014). In every organization, everyone who is a Human Resource (HR) has a desire to get respect and fair treatment from their leaders. So that employees make a meaningful contribution to the organization or company where they work and vice versa.

Extra-role behavior is also called Organizational Citizenship Behavior (OCB). According to Robbins and Judge (2015), organizations that have employees who have good OCB will have better work performance. Extra role behavior is work behavior that exceeds specific performance standards. Extra role behavior has important implications for the organization, because it refers to the work behavior of employees related to the organization and other colleagues. In addition, the positive attitude of employee extra role behavior has a positive influence on the efficiency and effectiveness of overall organizational performance.

$O C B$ is an individual contribution that exceeds the demands of the role in the workplace and is rewarded by the acquisition of task performance. OCB involves several behaviors of helping others, volunteering for extra tasks, obeying rules and procedures in the workplace. These behaviors illustrate the "added value of employees" and are a form of prosocial behavior, namely social behavior that is positive, constructive and meaningful to help. The duties of the leader will be lighter if there are employees with high OCB, so that the consequences will increase their productivity and success (Hardaningtyas, 2005). If employees in an organization have OCB, employees can control their own 
behavior so that they are able to choose the best behavior for the benefit of their company.

Having employees with high work abilities, commitment and loyalty to agencies is not an easy thing because many factors influence it, one of which is organizational commitment (Luthans, 2006). Luthans (2006) defines organizational commitment as a strong desire to remain a member of a particular organization; the desire to try hard in accordance with the wishes of the organization; and certain beliefs, and acceptance of the organization's values and goals. Organizational commitment is a collection of feelings and beliefs that these people have the organization as a whole (George and Jones in Rini, et al., 2013). Employees who have a high commitment to the organization, will carry out tasks that are not only tasks that have become their obligations, but also do other work, where if there are employees who are unable to do a job, then these committed employees will tend to help their colleagues to achieve the goals expected by the organization without comparison -Compare his abilities with other employees.

In the implementation provisions of government regulation number 46 of 2011 concerning the work performance assessment of civil servants, it is stated that based on Article 12 paragraph (2) of Law Number 43 of 1999 concerning Amendments to Law Number 8 of 1974 concerning Personnel Principles it is determined that for realizing that the administration of governmental and development tasks requires professional, responsible, honest and fair Civil Servants through coaching carried out based on a work performance system and a career system that focuses on the work performance system. Furthermore, Article 20 stipulates that to further ensure objectivity in considering appointments and promotions, work performance assessments are held. In order to carry out the mandate of Article 12 paragraph (2) and Article 20, appraisal of work performance of civil servants is carried out to evaluate the performance of civil servants who can provide guidance to officials with an interest in evaluating the performance of units and organizations. The results of the work performance appraisal for Civil Servants are used as a basis for consideration in determining the policy decisions for the career development of Civil Servants.

Employees who work in a government agency are required to be able to complete their duties and responsibilities effectively and efficiently because the performance of human resources is able to make a positive and beneficial contribution to government agencies (Sari, 2009). Human resources are the most valuable and most important assets or assets for an organization or company, because organizational success is largely determined by the human element (Ardana, et al., 2012: 3). According to Sari (2009) the success of an organization in retaining its employees cannot be achieved in an easy way, this can be realized through the organization's ability to understand the needs of employees so that it can provide job satisfaction for employees.

Public or private organizations in carrying out their activities will always need humans as dynamic resources and have the ability to continue to develop. Human Resources (HR) is one of the determinants of organizational success because the role of human resources as a valuable asset is to plan, implement and control various operational activities of the organization (Ardana, et al., 2012). To get professional, qualified and responsible Civil Servants, it is necessary to start from the process of procurement / appointment of employees. Employee recruitment / appointment is one of the main functions of Human Resource Management where the procurement and selection of employees are absolute demands that must be handled properly so that each employee obtained is in accordance with the required competencies.

Procurement of Civil Servants is a process of activities carried out by an organization to fill in vacant formations. Formation vacancies in a government organization in generaldue to the existence of civil servants who quit due to retirement, death, transfer of position, organizational development or other causes. Because the procurement of Civil Servants is intended to fill the vacant formations. Therefore, the procurement of employees is carried out on the basis of the need for additional employees, both in terms of number, quality of employees and required job competencies.

In the Law of the Republic of Indonesia Number 3 of 2005 in CHAPTER XIX, Article 86 paragraph (1), it is stated that every sports player, sports organization, government / private institution, and individuals who excel and / or contribute in advancing sports are given an award. Furthermore, in paragraph (2) the award as intended in paragraph (1) is given by the Government, Regional Government, Sports Organization, other organizations and / or individuals. In order to carry out the mandate of Article 86 paragraph (1) and (2) of the Law, the Provincial Government of Bali in 2009 carried out the procurement of civil servants consisting of a general formation in which there is a formation for Sports Trainers. The formation consists of athletes and sports coaches who have competence and achievement in various sports. The spotlight in the recruitment of employees at that time was the procurement of Sports Trainer Civil Servant Candidates. The procurement of Sports Trainer Civil Servant Candidates is a form of government appreciation in giving awards to sports people who excel in the name of the region as well as the nation and state and aim to improve national and international sports achievements to be placed in all agencies that need them, both in central and regional agencies., so that sports coaching can be more structured, systematic and stable.

The problem that arises when these outstanding sports people are appointed to become Civil Servants is whether the sports players are able to maintain or improve their achievements both in their respective sports fields and in the organizations to which they are assigned? Because after being appointed as a Civil Servant, there are 2 tasks that must be carried out at once, namely as a state servant serving the community and as a sports person who is required to continue to excel or develop themselves in increasing the dignity of the region and the state in the field of sports.

From the results of interviews and observations conducted, several obstacles were found, namely: difficulties in obtaining dispensation from the leadership for training or competing on weekdays or working hours. Second, jealousy among employees, because when PNS sports coach formations carry out 
training or competition dispensations, they still receive the same performance allowance as civil servants who work in the office. Third, employees who come from the formation of sports coaches have difficulty managing their training time and working time at the office. Sometimes they have to overtime complete the tasks given by the leader so that the two activities carried out can run well without having to sacrifice one of them.

To evaluate the work performance of civil servants who are appointed through sports achievements, it is necessary to pay attention to several factors that can influence, namely leadership, organizational commitment and organizational citizenship behavior (OCB). So that employee work performance is always consistent, at least the leaders in the organization always pay attention to employees in carrying out their duties. In addition, the policies given will encourage employees to do their best in carrying out their duties because they believe that with the success of the organization in achieving its goals and objectives, the personal interests of the members of the organization will also be covered.

This research was conducted in each of the Regional Apparatus Organizations within the Bali Provincial Government. The number of civil servants who are appointed through sports achievements consists of 33 people who are scattered in each of the Regional Apparatus Organizations of the Bali Provincial Government.The reason for this research is the research problems found in the field. Different policies of leaders, the desire to remain in the organization where they work lead to extra behavior by employees and have an impact on work performance.

This study uses leadership variables and organizational commitment to see their effect on organizational citizenship behavior (OCB) and work performance. In addition, this study also examines the indirect effect of leadership variables on work performance, organizational commitment variables on work performance through organizational citizenship behavior (OCB) variables, with the hope that the presence of high OCB from employees can also increase achievement so that organizational performance will react. positive (increasing). Based on the background of this problem, it is necessary to conduct research on "The Influence of Leadership and Organizational Commitment on Organizational Citizenship Behavior and Work Achievement in Civil Servants of Sports Coach Formations in the Bali Provincial Government".

\section{LITERATURE REVIEW}

\section{Work performance}

Role of sHuman resources in the organization are important, because human resources are the basic capital in determining whether the objectives have been achieved or not. In order to achieve organizational goals, it requires human resources who have high work performance. Thus it is necessary to have proper and fair treatment, as well as guidance and development of employee work performance effectively, so that they will be able to carry out their duties seriously and responsibly and have high organizational commitment.Siregar (2019) examines the effect of leadership and remuneration on work performance, the results of the study explain that the influence of leadership on work performance has a positive and insignificant effect of 0.674 . Research by Darmawati, Arum, et al. (2013) found that organizational commitment did not have an influence on the OCB variable. This is indicated by a significance value of 0.635 , which means it is greater than the significance value set at 0.05. In addition, Syamsuri's research (2018) analyzes the relationship between organizational commitment and work performance showing that the results of organizational commitment have a positive and insignificant effect on work performance. However, in this study the proposed hypothesis is different from the three previous studies.

\section{Leadership}

There are two main factors that can trigger OCB behavior, namely external factors and internal factors. Internal factors include job satisfaction, commitment, personality, and motivation. Meanwhile, external factors include leadership style, trust in leaders, and organizational culture (Organ, 2006; Titisari, 2014; Heaviana, 2017). MacKenzie, et. al (1998) in the field of organization found that one of the most important factors in forming Organizational Citizenship Behavior (OCB) is leadership in organizations.

The results of research from Sandhora Yunina et al (2018) show the relationship between Leadership Style and Organizational Commitment to Organizational Citizenship Behavior (OCB). In his research, Leadership Style and Organizational Commitment are independent variables that have a positive and significant effect on Organizational Citizenship Behavior (OCB) of the DPRK Bireuen secretariat employees.

Good leadership is good communication made by superiors by accepting all input to improve work quality and establishing good relationships with all colleagues and working together to increase work productivity. According to Budiarta (2010) leadership is a way for a leader to influence the behavior of subordinates, so that they are willing to cooperate and work productively to achieve organizational goals.

Colquitt et al's integrative model of organizational behavior. (2011) stated that the group mechanism factor, including leadership style, has a direct effect on individual output, including performance or work performance. This is evidenced by research conducted by Lika Dora (2016) showing the influence of Leadership Style, Intensive and Work Environment on Employee Work Performance. The results showed that there was a significant influence of leadership style on employee job performance.

\section{Organizational Commitment}

Jha and Jha (2010) suggest that the factors that influence the emergence of OCB are individual dispositions and motives, group cohesiveness, employee 
attitudes which include organizational justice, organizational commitment and job satisfaction.

Organizational citizenship behavior (OCB) is also influenced by organizational commitment. This is evidenced by Widyanto et al. (2013) who argued that commitment is one of the factors that are known to have a strong influence on OCB behavior. This is evidenced by research conducted by Erlina Wahyuni (2019) showing the influence of Organizational Justice, Organizational Commitment and Job Satisfaction on OCB. In his research, Organizational Commitment is an independent variable that has a positive and significant effect on OCB of employees at Dash Hotel Seminyak.

Having employees with high work abilities, commitment and loyalty to agencies is not an easy thing because many factors influence it, one of which is organizational commitment (Luthans, 2006). Luthans (2006) defines organizational commitment as a strong desire to remain as a member of a particular organization, a desire to strive according to organizational desires and certain beliefs, and acceptance of organizational values and goals.

Hasibuan (2007) states that work performance is a result of work achieved by an employee in carrying out the tasks assigned to him based on skill, experience and seriousness and time. Meanwhile, employee work performance is influenced by the commitment of the employee itself because with high commitment the employee will work optimally so that the results achieved or work performance will increase. This is evidenced by research conducted by Syukriadi (2019) showing the influence of Organizational Commitment and Training on Work Performance through Employee Work Motivation at the Ministry of Religion, Bulukumba Regency. The results showed that organizational commitment as an independent variable has a positive and significant effect on work performance at the Ministry of Religion, Bulukumba Regency.

\section{Organizational Citizenship Behavior}

Good work performance requires employees not only to do the main job (in-role) of the employee but also work that is outside the employee's main job (extra-role) (Titisari, 2014).Extra-role behavior is also called Organizational Citizenship Behavior (OCB). According to Robbins and Judge (2015), organizations that have employees who have good OCB will have better work performance. This is evidenced by research conducted by Dewanggana et al. (2016) showing the influence of Organizational Commitment, Job Satisfaction, Organizational Culture on Organizational Citizenship Behavior (OCB) which has an impact on Employee Performance. The results showed that Organizational Citizenship Behavior (OCB) as an intervening variable had a positive and significant effect on work performance.

\section{Hypothesis}

1) H1: Leadership has a positive and significant effect on Organizational Citizenship Behavior $(O C B)$
2) H2: Organizational commitment has a positive and significant effect on Organizational Citizenship Behavior (OCB)

3) H3: Leadership has a positive and significant effect on Work performance.

4) H4: Organizational commitment has a positive and significant effect on Work performance

5) H5:Organizational Citizenship Behavior (OCB) positive and significant effect on Work performance

\section{RESEARCH METHODS}

The location in this research was carried out in the environment of the Bali Provincial Government because civil servants who were appointed from sports coach formations were scattered in each of the Regional Apparatus Organizations of the Bali Provincial Government. The object of this study is the influence of leadership and organizational commitment on organizational citizenship behavior (OCB) and work performance in civil servants of sports coach formations in the Bali Provincial Government.The population in this study were all civil servants who were appointed to sports coach formations in the Bali Provincial Government, totaling 33 people. The population in this study was 33 people, so this study was conducted on 33 civil servants of sports coach formation.

In this study, there are two types of variables studied, namely: Independent variables or independent variables are variables that affect other variables. In this study, the independent variables are leadership (X1) and organizational commitment (X2). The dependent variable or dependent variable is a variable that is influenced by other variables. In this research, the dependent variable is the Organizational Citizenship Behavior (OCB) (Y1) and Job Performance (Y2).

The data collection method used in this study is a survey method with a questionnaire. The questionnaire is a data collection technique carried out by giving a set of questions or written statements to the respondent to answer (Sugiyono, 2014: 199). In this study, the questionnaire will be delivered directly to the target respondents to the research location, namely the PNS Sports Coach Formation in the Bali Provincial Government. Distributed questionnaires in the form of a list of questions and written statements to respondents regarding the influence of leadership and organizational commitment on work performance with organizational citizenship behavior as a mediator.

Assessment of the variables identified in leadership and organizational commitment to work performance mediated by organizational citizenship behavior was carried out using a Likert scale. Data collection was carried out by means of a set of questionnaires in the form of a Likert scale, then given directly to respondents to fill them in. Respondents chose the answer categories strongly agree (SS), Agree (S), disagree (KS), disagree (TS), strongly disagree (STS) by giving a cross (X). on the answer that feels suitable. For the Likert scale score, the answers are weighted equal to the quantitative value of 5,4,3,2,1. For positive questions, and 1,2,3,4,5 for negative questions. The compilation of the questionnaire was followed in several stages, namely: determining variable indicators, and developing question items. This research hypothesis testing was carried out using the Structural Equation Model (SEM) approach based on Partial Least Square (PLS). 


\section{RESEARCH RESULTS AND DISCUSSION}

Data analysis

Inferential analysis in this study using the SEM PLS model and processed with SmartPLS version 3.2.8 to evaluate the research model. The inferential analysis stage consists of several steps, including: (1) evaluating the measurement model (outer model) to determine the validity and reliability of the indicators that make up each latent variable, (2) evaluating the structural model (inner model) to determine accuracy of the model, and (3) hypothesis testing.

\section{Assessing the Outer Model}

1. Convergent validity. The variable indicator is considered to have a good convergent validity if it has an AVE value of more than 0.5 (Ghozali \& Latan, 2015: 74). Based on the research results, it can be seen that all indicator variables have a value of 0.5 .

2. Discriminantvalidity. The model is said to have good discriminant validity if each indicator loading value of a latent variable is $>0.7$ or has the square root of AVE that is greater than the correlation value between other latent variable constructs (Ghozali, 2014: 40). The results of discriminant validity testing on this panel showed that the square root value of AVE was more than 0.7.

3. Composite Reliability. The construct is done by measuring Cronbach's alpha and composite reliability. A construct that is declared reliable is if the Cronbach's alpha value and composite reliability are above 0.7 (Ghozali \& Latan, 2015: 76-77). The results of the composite reliability test explained that all of the variables in this study had met Cronbach's alpha and composite reliability because the value was above the recommended number, which was above 0.7 which had met the criteria for reliability. Based on the results of the overall evaluation, both convergent, discriminant validity and composite reliability that have been described above, it can be concluded that the indicators that measure latent variables are valid and reliable measures.

\section{Inner Model Testing}

Figure 1

Structural Model (Inner Model)

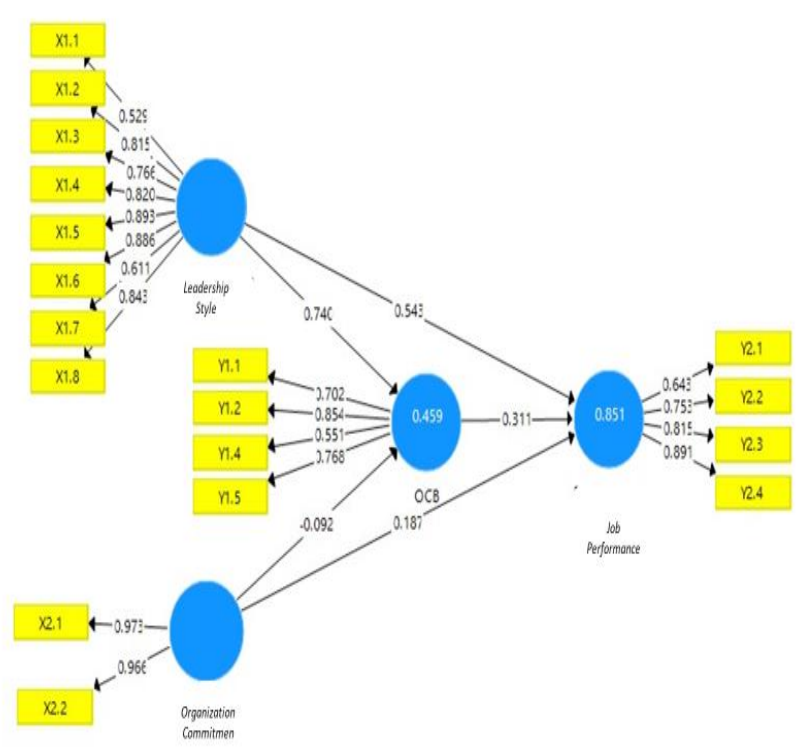

Source: processed data, 2020

Model assessment with PLS begins by looking at the $\mathrm{R}$-square for each dependent latent variable. Changes in the Rsquare value can be used to assess the effect of certain exogenous latent variables on endogenous latent variables that have a substantive effect. Table 1 shows the results of the Rsquare estimation using SmartPLS.

Table 1

R-Square Value

\begin{tabular}{|l|c|}
\hline \multicolumn{1}{|c|}{ Variable } & R-Square \\
\hline OCB(Y1) & 0.459 \\
\hline Job Performance (Y2) & 0851 \\
\hline
\end{tabular}

Source: processed data, 2020

Table 1 shows the R-square value of the ocb variable of 0.459 and the work performance variable of 0.851 . The higher the R-square value, the greater the ability of the exogenous variables to be explained by the endogenous variables so that the better the structural equation (Ghozali, 2014: 42).

\section{Hypothesis test}

Hypothesis testing is done using t-statistics by sorting for testing the direct and indirect effects or testing the mediating variables. The following sections describe the results of the direct effect test and the mediating variable test, respectively.

1) Direct Effect Testing. The significance of the parameters estimated provides very useful information about the relationship between the research variables. The basis used in testing the hypothesis is the value contained in the output result for inner weight. Table 3 provides the estimated output for structural model testing. 
Table 2

Hypothesis Testing Results

\begin{tabular}{|l|c|c|}
\hline & $\begin{array}{c}\text { Path coefficient } \\
\text { (Bootsrapping) }\end{array}$ & p-values \\
\hline Leadership -> OCB & 0.740 & 0.000 \\
\hline $\begin{array}{l}\text { Leadership Job } \\
\text { Performance }\end{array}$ & 0.543 & 0.000 \\
\hline $\begin{array}{l}\text { Organizational Commitment } \\
\text {-> OCB }\end{array}$ & -0.092 & 0.687 \\
\hline $\begin{array}{l}\text { Organizational Commitment } \\
\text {-> Job performance }\end{array}$ & 0.187 & 0.294 \\
\hline OCB -> Job performance & 0.311 & 0.016 \\
\hline
\end{tabular}

Source: processed data, 2020

The results of testing the research hypothesis based on Table 2 are as follows:

1) Testing Hypothesis 1: There is a positive and significant influence between leadership on organizational citizenship behavior (OCB) in the Sports Coach Formation Civil Servants in the Bali Provincial Government Environment. This result can be seen in the path coefficient value of0.740with a p-value of 0,000 . The p-value is less than 0.05 (alpha 5\%). Based on this, hypothesis 1 is accepted.

2) Testing Hypothesis 2: There is a negative and insignificant influence between organizational commitment to organizational citizenship behavior (OCB) on Civil Servants of the Sports Coach Formation in the Bali Provincial Government. This result can be seen in the path coefficient value of -0.092 with a p-value of 0.687 . The $\mathrm{p}$ value is more than 0.05 (alpha 5\%). Based on this, hypothesis 2 is rejected.

3) Testing Hypothesis 3: There is a positive and significant influence between leadership on work performance in the Sports Coach Formation Civil Servants in the Bali Provincial Government. This result can be seen in the path coefficient value of 0.543 with a p-value of 0,000 . The pvalue is less than 0.05 (alpha 5\%). Based on this, hypothesis 3 is accepted.

4) Testing Hypothesis 4: There is a positive and insignificant influence between organizational commitment on work performance of the Sports Coach Formation Civil Servants in the Bali Provincial Government Environment. This result can be seen in the path coefficient value of 0.187 with a pvalue of 0.294 . The p-value is more than 0.05 (alpha 5\%). Based on this, hypothesis 4 is rejected.

5) Testing Hypothesis 5: There is a positive and significant influence between organizational citizenship behavior on job performance in the Sports Coach Formation Civil Servants in the Bali Provincial Government. This result can be seen in the path coefficient value of 0.311 with a $\mathrm{p}$-value of 0.016. The p-value is less than 0.05 (alpha 5\%). Based on this, hypothesis 5 is accepted.

Based on the results of tests carried out using the SmartPLS 3.0 application, an image of the following research model can be presented:
Figure 2

Full Structural Model (PLS Bootstraping)

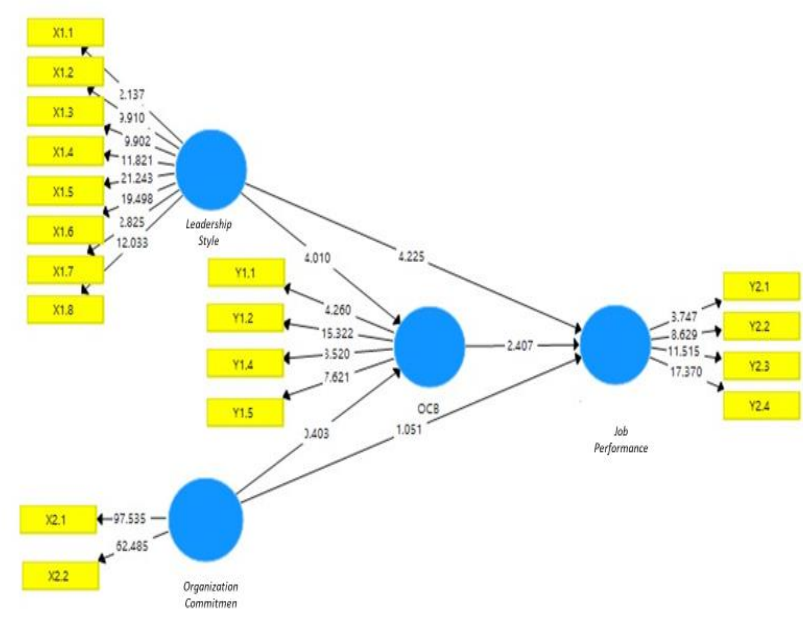

Source: processed data, 2020

2. Testing the Indirect Effect through Mediation Variables The significance of the parameters estimated provides very useful information about the relationship between the research variables. The basis used in testing the hypothesis is the value contained in the output result for inner weight. Table 4 provides the estimated output for partial model testing.

Table 2

Test result Indirect Influence

\begin{tabular}{|l|c|c|}
\hline & \multicolumn{1}{|c|}{$\begin{array}{c}\text { Path } \\
\text { coefficient } \\
\text { (Bootsrapping) }\end{array}$} & p-values \\
\hline $\begin{array}{l}\text { Leadership -> OCB -> } \\
\text { Job Performance }\end{array}$ & 0.230 & 0.029 \\
\hline $\begin{array}{l}\text { Organizational } \\
\text { Commitment -> OCB - } \\
>\text { Job Performance }\end{array}$ & -0.028 & 0.705 \\
\hline \multicolumn{2}{|l|}{ Source: data processed, 2020}
\end{tabular}

The results of testing the indirect effect through the mediation variable based on table 2 are as follows:

a) OCB (Y1) is able to positively and significantly mediate the indirect effect of leadership (X1) on work performance (Y2). This result can be seen in the p-value of 0.029 . The p-value is less than 0.05 (alpha 5\%). The results of the analysis in table 5.16 show that the direct effect of leadership on work performance has a path coefficient of 0.543 with a p-value of 0.000 . Whereas in table 5.17 , it can be seen that the indirect effect of leadership on work performance through OCB has a path coefficient of 0.230 with a p-value of 0.029 . The path coefficient proves that leadership has a greater direct influence on work performance than the indirect effect of leadership on work performance through OCB.

b) OCB (Y1) does not mediate the indirect effect of organizational commitment (X2) on work performance (Y2). This result can be seen in the p-value of 0.705 . The p-value is more than 0.05 (alpha 5\%). The results of the analysis in table 5.16 show that the direct effect of 
organizational commitment on work performance has a path coefficient of 0.187 with a p-value of 0.304 . Whereas in table 5.17, it can be seen that the indirect effect of organizational commitment on work performance through OCB has a path coefficient of -0.028 with a p-value of 0.705 . The path coefficient proves that organizational commitment has a greater direct effect on work performance than the indirect effect of organizational commitment on work performance through OCB.

\section{Discussion}

Based on the results of the analysis, this section will discuss the results of the calculations that have been carried out. This study aims to determine the effect of leadership and organizational commitment on organizational citizenship behavior (OCB) and work performance of the Sports Coach Formation Civil Servants in the Bali Provincial Government Environment. Testing is shown through existing hypotheses so that we can find out how each variable affects the other variables.

The results of statistical data analysis show that leadership has a positive and significant effect on organizational citizenship behavior (OCB) in the Sports Coach Formation Civil Servants in the Bali Provincial Government Environment. This result can be seen in the path coefficient value of 0.740 with a p-value of 0.000 . The analysis of this research model shows that good leadership is able to make employees perform Organizational Citizenship Behavior (OCB). The behavior of a leader who is able to be fair, give suggestions, support the achievement of goals, as a catalyst, create a sense of security, as an organization representative, a source of inspiration and respect will increase employee OCB behavior. An increase in OCB which is marked by an increase in the initiative of employees to want to help or help fellow colleagues, willing to always maintain good relations with fellow colleagues so that no disputes occur. Willing to accept and carry out every procedure established by the organization, as well as to be involved and participate in every activity planned and organized by the organization. OCB of employees can be increased by increasing the intensity of leadership implementation. The results of this study are supported by research conducted by R. Jati Nurcahyo (2012).which states that leadership has a positive and significant effect on Organizational Citizenship Behavior (OCB).

The results of statistical data analysis show that organizational commitment has no effect on the Organizational Citizenship Behavior (OCB) of the Sports Coach Formation Civil Servants in the Bali Provincial Government Environment. This result can be seen in the path coefficient value of -0.092 with a p-value of 0.697 . The analysis of this research model shows that high organizational commitment does not cause a person to carry out Organizational Citizenship Behavior (OCB). This is possible because the willingness of employees to strive for the achievement of organizational interests has been stated in the work goals of employees, so that it does not always cause employees to carry out Organizational Citizenship Behavior (OCB). The results of this study are different from those conducted by Sadhora Yunina et al., (2018)stated that organizational commitment has a positive and significant effect on Organizational Citizenship Behavior (OCB), but according to research conducted by Arum Darmawati, et al. (2013) found that Organizational
Commitment did not have an influence on variablesOrganizational Citizenship Behavior (OCB).

The results of statistical data analysis show that leadership has a positive and significant effect on work performance of the Sports Coach Formation Civil Servants in the Bali Provincial Government, with a path coefficient value of 0.543 with a p-value of 0.000 . The analysis of this research model shows that good leadership will lead to high job performance. The behavior of leaders who are able to be fair, give suggestions, support the achievement of goals, as a catalyst, create a sense of security, as an organizational representative, a source of inspiration and have a respectful attitude will improve employee work performance. The increase in employee work performance is marked by the increase in work quality and quantity of work of employees in a relatively short period of time so as to maximize the use of time for other activities while still paying attention to the use of costs. Employee work performance can be improved by increasing the intensity of leadership application. The results of these studies are supported by research conducted byWiwick Harwiki (2015) which states that leadership has a positive and significant effect on employee performance. The Organizational Citizenship Behavior (OCB) variable in this study was able to mediate the indirect effect of leadership on work performance. Based on these results it can be stated, Organizational Citizenship Behavior (OCB) obtained from leadership is able to improve work performance in the Sports Coach Formation Civil Servants in the Bali Provincial Government, so that these results can be interpreted as the influence of a leader in improving employee work performance is very important so that A leader must have the values contained in the leader's criteria, one of which is as a catalyst that is able to generate enthusiasm and fast working power of employees as much as possible.

The results of statistical data analysis show that organizational commitment has no effect on work performance of the Sports Coach Formation Civil Servants in the Bali Provincial Government. These results can be seen in the path coefficient value of 0.187 with a p-value of 0.304 . The analysis of this research model shows that high organizational commitment does not support employee performance. This may occur because what is being studied are government agencies that have different mindsets with non-government agencies, where there is a thought that being a civil servant does not have to show high work performance because of the old age security that they will definitely get when they retire. so that their current existence as employees is not to achieve achievement but to fulfill their living expenses and their future security when they retire. If there are some employees with higher achievement this is due to several reasons such as (1) there is desire and ability to achieve from within; and (2) personally they like the leadership. This may also occur due to the placement of the Sports Coach Formation Civil Servants who are scattered in several Regional Apparatus Organizations that have different core businesses so that they do not support work performance in the sports field. The results of this study are different from the research of Salim Musabah Bakhit Al Zefeiti et al (2017), but are the same as research conducted by Syamsuri, AR.The Organizational Citizenship Behavior (OCB) variable in this study has not been able to mediate the indirect effect of organizational commitment on work performance. Based on these results it can be stated, Organizational 
Citizenship Behavior (OCB) obtained from organizational commitment has not been able to improve work performance in the Sports Coach Formation Civil Servants in the Government of Bali Province, so that these results can be interpreted that work performance can be improved if employees have a commitment to organization because of a strong desire to remain a member of the organization.

The results of statistical data analysis show that organizational citizenship behavior has a positive and significant effect on job performance of the Sports Coach Formation Civil Servants in the Bali Provincial Government. This result can be seen in the path coefficient value of 0.311 with a p-value of 0.017 . The analysis of this research model shows that high employee Organizational Citizenship Behavior (OCB) supports employee work performance.. Behavior Organizational Citizenship Behavior (OCB) is high such as increasing cooperation between employees, proactive assistance in solving problems for others, and willingness to attend and participate in organizational activities and meetings, this can change the mind and social atmosphere of the organization, thereby further enhancing employee work performance.The results of this study are in accordance with research conducted by Wiwik Harwiki (2015) which states that leadership has a positive and significant effect on work performance.

\section{CONCLUSIONS AND RECOMMENDATIONS Conclusion}

Based on the discussion of the research results, it can be concluded that the influence of leadership and organizational commitment on organizational citizenship behavior (OCB) and work performance is as follows :

1. Leadership has a positive and significant effect onorganizational citizenship behavior (ocb) on the Civil Servants of the Sports Coach Formation in the Bali Provincial Government, it matters the better the leadership in a regional apparatus organization, the better it is able to cause employees to do organizational citizenship behavior (ocb) which is marked by an increase in the initiative of employees to want to help or help fellow colleagues, willing to always maintain good relations with fellow colleagues, willing to accept and carry out every procedure established by the organization, and to be involved and participate in every activity planned and organized by the organization.

2. Organizational commitment has no effect onorganizational citizenship behavior (ocb) on the Civil Servants of the Sports Coach Formation in the Bali Provincial Government, it matters high organizational commitment does not always cause an employee to doorganizational citizenship behavior (ocb).

3. Leadership has a positive and significant effect on work performance of the Sports Coach Formation Civil Servants in the Bali Provincial Government, this means that good leadership is able to improve employee performance both in the organization and employee performance in the sports field. On the other hand, the variable organizational citizenship behavior (OCB) is able to mediate the leadership variable on work performance. This shows that the influence of a leader in improving employee work performance is very important because the leader is a catalyst that is able to generate enthusiasm and fast working power of employees as much as possible.

4. Organizational commitment has no effect on work performance of the Sports Coach Formation Civil Servants in the Bali Provincial Government,it mattersOrganizational commitment does not support the achievement of employee work performance both in the organization and in sports. On the other hand, the variable organizational citizenship behavior (OCB) has not been able to mediate the variable organizational commitment to work performance. So that these results can be interpreted that work performance can be improved if employees are committed to the organization because of a strong desire to remain a member of the organization.

5. Organizational Citizenship Behavior (OCB) has a positive and significant effect on Job performance of the Sports Coach Formation Civil Servants in the Bali Provincial Government, this means behavior of organizational citizenship behavior (OCB) which is high is able to increase the work performance of employees in the organization and achievement in the field of sports. Behavior Organizational Citizenship Behavior (OCB) is high such as increasing cooperation between employees, proactive assistance in solving problems for others, and willingness to attend and participate in organizational activities and meetings, being able to change the mind and social atmosphere of the organization, thereby further improving employee work performance.

\section{Suggestion}

Based on the results of the analysis and conclusions in this study, several things can be suggested:

1. Suggestions for the Bali Provincial Government dith the conclusion that the variable organizational commitment has no effect in this studyHowever, the leadership variable has a positive and significant effect in this study, so to improve and optimize the work performance of civil servants who are appointed to sports coach formations, the government should be able to form a forum for channeling the talents and competencies of employees in the sports field such as the formation of PPLPD (Sports Training Center Program. Regional Students). With the existence of this PPLD, the work performance of Civil Servants who are appointed to the sports coach formation can at least be measured and channeled, with the aim of regenerating and being able to increase national sports achievements.

2. Suggestions for further research can modify the research model by adding and developing indicators and other variables that affect OCB and work performance such as competency variables.

\section{REFERENCES}

[1] Al Zefeiti, SMB, \& Mohamad, NA (2017). The Influence of organizational commitment on Omani public employees' work performance. International Review of Management and Marketing, 7 (2), 151-160.

[2] Allen, NJ \& Meyer, JP (1993). The Measurement and Antecendents of Affective, Continuance, and Normative Commitment to The Organization. Journal of Occupatinal Psychology, vol: 63, pp. 1-18 
[3] Awanti, H., Fathoni, A., \& Malik, D. (2018). The Influence of Transformational Leadership, Job Satisfaction and Organizational Commitment on Organizational Citizenship Behavior (Empirical Study on Employees of the Marketing Division of PT. Indofood CBP Sukses Makmur (Nutrition \& Special Food) Semarang Branch). Journal of Management, 4 (4).

[4] Dewanggana, BD, Paramita, PD, \& Haryono, AT (2016). The Influence of Organizational Commitment, Job Satisfaction, Organizational Culture on Organizational Citizenship Behavior (OCB) which Impacts on Employee Performance (Study at PT. PLN App Semarang). Journal of Management, 2 (2).

[5] Dora, L. (2018). Leadership Style, Incentives and Work Environment on Employee Work Performance at the Bogor Regency Public Works and Spatial Planning Office. Journal of Management (Electronic Edition), 9 (1), 58-70.

[6] Hadiwijaya, H. (2017). Analysis of Organization Citizenship Behavior (OCB) and Work Discipline on Employee Performance.

[7] Hardaningtyas, D. (2005). "The Influence of Emotional Intelligence Levels and Attitudes on Organizational Culture on Organizational Citizenship Behavior (OCB) of PT. (Persero) Pelabuhan Indonesia III ", (Thesis), Surabaya: Airlangga University

[8] Harwiki, W. (2016). The impact of servant leadership on organization culture, organizational commitment, organizational citizenship behavior (OCB) and employee performance in women cooperatives. Procedia-Social and Behavioral Sciences, 219 (1), 283-290.

[9] Musringudin, M., Akbar, M., \& Karnati, N. (2017). The effect of organizational justice, job satisfaction, and organizational commitment on organizational citizenship behavior (OCB) of the principles. Ijer-Indonesian Journal of Educational Review, 4 (2), 155-165.

[10] Nurcahyo, RJ (2012). The Influence of Leadership, Job Satisfaction and Organizational Commitment on Organizational Citizenship Behavior (OCB) Nurses at RSD Panembahan Senopati Bantul. Synergy: Business and Management Studies, 13 (1).

[11] Government Regulation Number 11 of 2002 concerning Amendments to Government Regulation Number 98 of 2000 concerning Procurement of Civil Servants

[12] Puspitasari, NLMR (2014). The effect of perceived organizational support on work performance with OCB as a mediating variable. Matrix: Journal of Management, Business Strategy and Entrepreneurship.

[13] Reynaldi, R., Ridjal, S., \& Sjahruddin, H. (2019). The Role Of Organizational Citizenship Behavior In Work Performance: An Investigation Based On Hotel Employee Survey. European Journal of Business and Management Research, 4 (6).

[14] Rivai, Veithzal. (2009). Human Resource Management For Companies From Theory to Practice. Jakarta: Raja Grafindo Persada

[15]Robbins, SP and Judge TA (2015). Organizational behavior. Jakarta: Four Salemba.

[16]Robbins, SP (2006). Organizational behavior (organizational behavior). Jakarta: Salemba Humanika.

[17] Sedarmayanti (2011), Human Resource Management, Refika Aditama, Bandung.
[18] Simamora, Henry (2006), Human Resource Management, Printing Department STIE YKPN, Yogyakarta.

[19] Simamora. (2004). Resource Management Human. Jakarta: Publishers Section STIE YKPN.

[20] Soerosemito, VN, \& Cholil, M. (2018). The Influence of Transformational Leadership on Organizational Citizenship Behavior (OCB) with Communication Competencies and Motivation as Mediators. CAPITAL: JOURNAL OF ECONOMICS AND MANAGEMENT, 2 (1), 54-62.

[21] Sudarsono, H. (2019). The Influence of Transformational Leadership and Work Discipline on Employee Performance of Surabaya City Education Office. Social \& Humanities, 9 (2), 128-157.

[22] Tran, TBH, \& Choi, SB (2019). Effects of inclusive leadership on organizational citizenship behavior: the mediating roles of organizational justice and learning culture. Journal of Pacific Rim Psychology, 13.

[23] Udayana, KJ, Nuridja, IM, \& Suwena, KR (2015). The Effect of Organizational Commitment on Employee Performance of PT. Sekar Nusa Baruna, Singaraja Branch, 2015. Journal of Economic Education, Undiksha, 5 (1).

[24] Wahjosumidjo. 1991. Effective Leadership. Yogyakarta: Balai Pustaka.

[25] Yunina, S., Arifin, AH, \& Yanita, Y. (2018). The Influence of Leadership Style and Organizational Commitment to Organizational Citizenship Behavior with Job Satisfaction as an Intervening Variable at the Bireuen DPRK Secretariat. Indonesian Journal of Management (JMIND), 3 (2). 